\title{
Reform in medical and health sciences educational system: a Delphi study of faculty members' views at Shiraz University of Medical Sciences
}

\author{
A. Salehi, ${ }^{1}$ N. Harris, ${ }^{1}$ F. Lotfi, ${ }^{2}$ N. Hashemi, ${ }^{3}$ J. Kojouri ${ }^{3}$ and M. Amini ${ }^{3}$
}

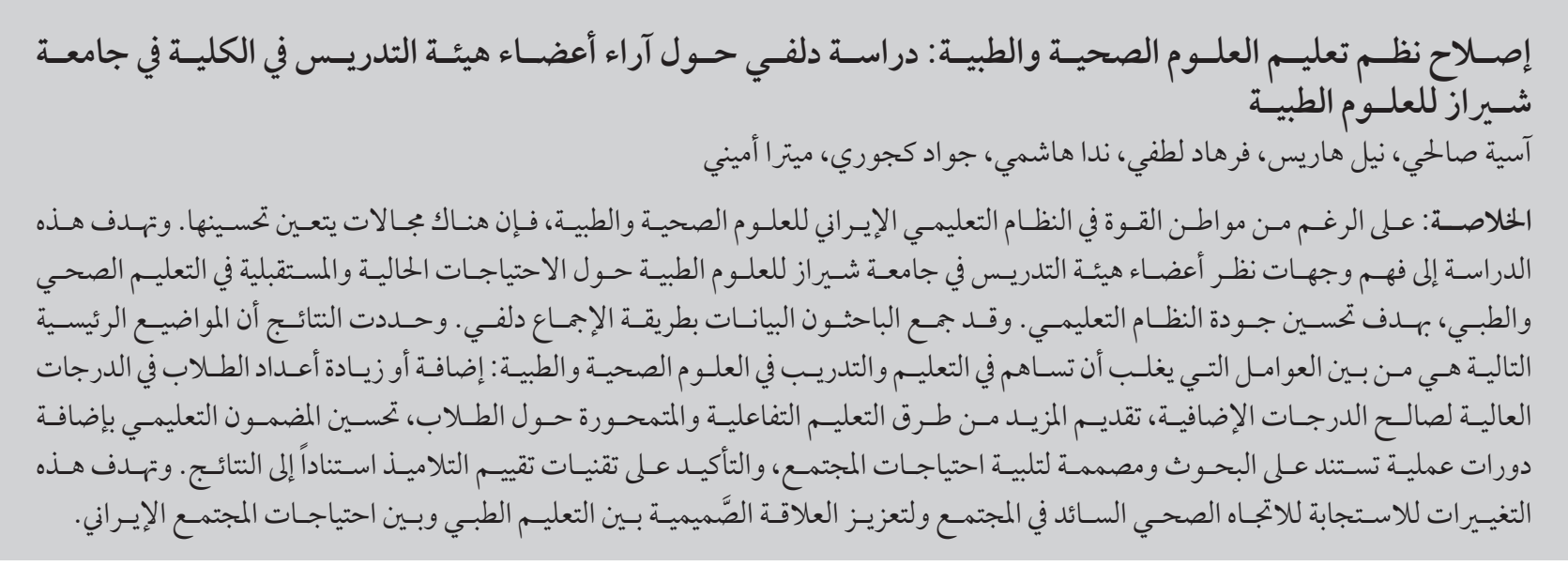

ABSTRACT Despite the strengths in the Iranian medical and health sciences educational system, areas in need of improvement have been noted. The purpose of this study was to understand the views of faculty members at Shiraz University of Medical Sciences about current and future needs for medical and health sciences education, with the goal of improving the quality of the educational system. The data were collected using a Delphi consensus method. Analysis of the findings identified the following key themes among the factors likely to contribute to medical and health sciences education and training: adding and/or increasing student numbers in higher degrees in preference to associate degrees; providing more interactive, student-centred teaching methods; improving the educational content with more practical and research-based courses tailored to society's needs; and an emphasis on outcome-based student evaluation techniques. These changes aim to respond to health trends in society and enhance the close relationship between medical education and the needs of the Iranian society.

Réforme du système d'enseignement de la médecine et des sciences de la santé : étude selon la méthode Delphi sur les points de vue des membres du corps enseignant de l'Université des Sciences médicales de Chiraz

RÉSUMÉ Malgré les aspects positifs du système iranien d'enseignement de la médecine et des sciences de la santé, certains domaines nécessitant une amélioration ont été identifiés. La présente étude visait à comprendre les points de vue des membres du corps enseignant de l'Université des Sciences médicales de Chiraz sur les besoins présents et à venir de l'enseignement de la médecine et des sciences de la santé, avec pour objectif d'améliorer la qualité du système d'enseignement. Les données ont été recueillies à l'aide de la méthode de consensus Delphi. L'analyse des résultats a permis de dégager les thèmes clés suivants parmi les facteurs susceptibles de contribuer à l'enseignement de la médecine et des sciences de la santé ainsi qu'à la formation en la matière : augmenter le nombre d'étudiants dans les années d'études supérieures plutôt dans que celles des diplômes d'études générales ; proposer davantage de méthodes d'enseignement interactives et axées sur l'étudiant ; améliorer le contenu de l'enseignement par des cours davantage centrés sur la pratique et la recherche et adaptés aux besoins de la société ; et privilégier les techniques d'évaluation de l'étudiant reposant sur les résultats. Ces changements visent à répondre aux tendances en matière de santé dans la société et à renforcer le lien étroit entre l'enseignement de la médecine et les besoins de la société iranienne.

${ }^{1}$ School of Public Health, Griffith Health Institute, Griffith University, Queensland, Australia (Correspondence to A. Salehi: Nasim.Salehi@ griffithuni.edu.au). ${ }^{2}$ Health Management and Economics Research Center, Iran University of Medical Sciences, Tehran, Islamic Republic of Iran. ${ }^{3}$ Quality Improvement in Clinical Education Research Center, Shiraz University of Medical Sciences, Shiraz, Islamic Republic of Iran.

Received: 13/01/13; accepted: 23/06/13 


\section{Introduction}

Medical and health sciences teaching and practice are in a constant state of change in response to advances in medical knowledge and technologies [1]. To ensure an appropriately trained medical and health sciences workforce, the content, technology and processes utilized in medical and health sciences education must be revised regularly, underpinned by principles of curriculum integrity and currency [2]. Reforms in educational systems involve qualitative, objective and conceptual analyses, integrating views on a variety of phenomena through the cooperation of different faculties and experts. The purpose may be to determine long-term common goals, policies and strategies, and/or to identify short-term goals on the basis of the current situation with the aim of improving the educational system [3]. University faculty members are without doubt the present and future educational decision-makers. Improving any educational system - particularly for medical and health sciences education-requires their buy-in to the process, and they are central to identifying strategies and policies for change [4].

One of the most important achievements of the health system in the Islamic Republic of Iran has been the integration of medical and health science education within a health-care system that is responsible for public health, medical treatment and the management and planning of health and medical education $[4,5]$. Despite the strengths of the system, which aims to provide a more practical education based on society's needs, areas in need of improvement have been noted. These concern teaching methods, educational content, technology integration, programme evaluation, professional conduct and the acceptance of occupational and social responsibilities [6]. These identified limitations are consistent with the debate taking place at global forums such as the annual congress of the
Association for Medical Education in Europe [7], and in national plans such as those in Canada [8] and the United Arab Emirates [9].

The National 20-Year Horizon plan implemented by the Iranian Ministry of Health and Education has set the goal of placing the country at the top of the regional ranking in terms of medical and health sciences education system by 2025 . To gain insights into how this goal may be progressed, the present study sought the views of faculty members at Shiraz University of Medical Sciences (SUMS) on the operationalization of medical and health sciences education planning and reform at the institutional level. These insights will be a catalyst to greater debate and ultimately innovation in the development of a medium-term vision for medical and health sciences education for the Islamic Republic of Iran.

\section{Methods}

The data set for this research was collected through a 3-round Delphi study. The Delphi technique is a widely accepted method for gathering data from respondents within their domain of expertise. It is a means of consensusbuilding by using a cyclic process to collect data from a panel of selected participants. By using this process the participants are encouraged to reassess their initial judgements about the information provided in previous iterations. As such, the Delphi technique is useful for situations where individual judgements must be combined in order to address a lack of agreement or incomplete state of knowledge [10].

\section{Participants}

The participants were drawn from faculty members and staff researchers at SUMS. A sample of 150 faculty members from across the 8 faculties at SUMS were selected through purposeful sampling. The 150 potential participants were approached via a letter that included an explanation about the research along with an invitation to participate in the study; 138 of the invited individuals agreed to participate.

\section{Round 1}

The first round questionnaire was constructed from a literature review and consultation with members of the research team. The questionnaire was relatively unstructured, with open-ended questions, to increase the richness of the data collected and allow the participants free scope to elaborate on the topic under investigation [11]. Printed copies of the questionnaires were distributed to participants by internal mail, and all participants were instructed to return their completed questionnaire to the Educational Development Centre of SUMS during a specific period. The instrument comprised 6 questions:

1. What are your views on adding or omitting some degree programmes in different educational fields based on the current situation of the health system and society's needs?

2. What are your views on increasing or decreasing the number of students enrolled in different educational fields and/or degree programmes based on the current situation of the health system and current potential of the university?

3. What are your recommendations for improving the teaching methods?

4. What are your suggestions for enhancing the current educational contents on the basis of society's needs?

5. What are your recommendations for increasing the quality of the recent methods of evaluation and assessment?

6. What other reforms do you recommend for improving the current situation of education at SUMS according to the current potential of the university and existent needs in society?

Each response from round 1 was listed as a separate item. Three of the authors 
as the Delphi coordinators independently reviewed these and clustered similar ideas together into themes. Then they named the themes and wrote a brief statement describing them.

\section{Round 2}

In the second round participants were presented with the items generated from round 1 organized into the themes. Consistent with a Delphi process, participants were asked to indicate their agreement about implementing each item in the SUMS education system, using a 10-point scale ranging from completely disagree to completely agree. Space was provided for comments at the end of each theme with this question: "What other reforms do you recommend in this field?" At the end of the questionnaire the respondents were asked to state any other suggestions and opinions to improve the total status of education at SUMS. In this round, the additional comments of respondents were collated, listed as separate items and organized beneath the appropriate theme.

To analyse the data, the total mean score for the participants was calculated for each item. A total mean score of $1-5$ was considered as disagreement and 6-10 was regarded as agreement. Items with a total mean score of 5 or below were excluded from the next round. In order to measure the homogeneity of rankings, a Cronbach alpha was calculated.

\section{Round 3}

In round 3 the research questionnaire presented a list of agreed items remaining from previous rounds, which showed the total mean scores of each item as well as the individual's own scores for comparison. New items based on comments received from Delphi participants from the previous round were included. Participants were requested to repeat the agreement scoring after taking the round 2 results into account. They were reminded that they were free to change their vote based on the results, or to vote the same way as they had in round 2. Space was again made available at the end of each theme as well as at the end of the questionnaire for optional comments.

To analyse the data in this round, the total mean score for each item was calculated as in round 2, then items in which the mean score was 5 or below were excluded. Cronbach alpha was calculated again as a measure of homogeneity for the ratings.

\section{Results}

\section{Participants}

Out of 138 Delphi team members, the number of respondents in round 1 was 131 (response rate of 95\%) and in the second and third rounds the numbers responding decreased to 102 (77.9\%) and $62(60.8 \%)$ respectively.

The distribution of Delphi team members in the first round according to their academic rank/university degree showed that $17.4 \%$ were professors, $35.0 \%$ associate professors, $31.2 \%$ assistant professors and $26.1 \%$ instructors. In terms of faculty members' length of employment at SUMS, 9.4\% had 26-30 years, $16.7 \%$ had $21-25$ years, $21.0 \%$ had $16-20$ years, $17.4 \%$ had $11-15$ years, $1.7 \%$ had $6-10$ years and $18.8 \%$ had $1-5$ years work experience.

\section{Round 1}

A total of 1632 ideas and suggestions were generated in the open questionnaire in round 1. Following discussion and analysis, the number of items was reduced to 304 in 7 themes. The themes which were agreed corresponded to the initial list of questions: degree programmes to be added; degree programmes to be omitted; degree programmes in which student numbers be increased; degree programmes in which student numbers be decreased; teaching methods; educational content; and evaluation techniques.

\section{Round 2}

In the second round participants were presented with the 304 items organized into the 7 themes generated from round 1. After scoring agreement about the importance for each item, 86 items in which the total mean score was $\leq 5$ were excluded from the study in round 2 . Since the Cronbach value extracted from the data of the second round was 0.62 , consensus was not reached in this round and the Delphi method was continued into the third round.

In round 2 items related to degree programmes to add to the course were omitted, such as the Msc in Sports Medicine and Msc in Traditional and Complementary Medicine. Also some items related to which degree programmes should increase the number of students were omitted such as Msc in Health Services Management.

\section{Round 3}

In the third round the list of 216 items remaining from previous rounds was presented and agreement about importance was scored again. In this round 74 items in which the mean score was $\leq 5$ were excluded from the study. Cronbach alpha was 0.87 and the Delphi process was judged to have achieved consensus and the rounds were stopped.

Tables 1 to 7 show the total mean and standard deviation (SD) points allocated to consensus items in rounds 2 and 3 based on the 7 research themes. The items in each table are ranked from the most important to the least important according to the total mean scores in the third round. For most items a smaller SD of the mean was achieved in round 3 , demonstrating better agreement on items.

\section{Educational programmes}

Tables 1 and 2 show Delphiparticipants' agreement about degree courses to be added to or omitted from the course offerings of SUMS, while Tables 3 and 4 show the programmes in which the 


\begin{tabular}{|c|c|c|c|c|}
\hline \multirow[t]{2}{*}{ Rank } & \multirow[t]{2}{*}{ Degree } & \multirow[t]{2}{*}{ Subject } & \multirow{2}{*}{$\begin{array}{r}\text { Round } 2 \\
(n=102) \\
\text { Mean (SD) }\end{array}$} & \multirow{2}{*}{$\begin{array}{c}\text { Round } 3 \\
(n=62) \\
\text { Mean (SD) }\end{array}$} \\
\hline & & & & \\
\hline 1 & MSc & Genetics & $9.0(1.6)$ & $9.8(0.5)$ \\
\hline 2 & $\mathrm{MSc}$ & Rehabilitation & $9.1(1.0)$ & $9.5(0.7)$ \\
\hline 3 & $\mathrm{MSc}$ & Health information management & $8.7(0.9)$ & $9.5(0.5)$ \\
\hline 4 & $\mathrm{BSc}$ & Medical information technology & $9.0(0.7)$ & $9.5(0.7)$ \\
\hline 5 & $\mathrm{PhD}$ & Oncology & $8.5(1.7)$ & $9.4(1.2)$ \\
\hline 6 & MSc & Medical education & $8.9(0.9)$ & $9.3(0.7)$ \\
\hline 7 & Subspecialty & Dermatology & $8.8(1.2)$ & $9.3(0.8)$ \\
\hline 8 & $\mathrm{PhD}$ & Midwifery \& fertility health & $8.5(0.8)$ & $9.2(0.6)$ \\
\hline 9 & MSc & Drug development & $8.4(1.9)$ & $9.0(1.4)$ \\
\hline 10 & MSc & Biotechnology & $8.0(1.5)$ & $8.9(0.9)$ \\
\hline 11 & $\mathrm{PhD}$ & Traditional \& complementary medicine & $7.5(0.7)$ & $8.9(0.6)$ \\
\hline 12 & MSc & Molecular biotechnology & $6.9(1.3)$ & $8.9(1.0)$ \\
\hline 13 & Fellowship & Rhinology ${ }^{a}$ & $7.4(1.9)$ & $8.8(1.4)$ \\
\hline 14 & Subspecialty & Angiography & $7.5(0.3)$ & $8.8(0.4)$ \\
\hline 15 & $\mathrm{PhD}$ & Medical education & $7.5(0.5)$ & $8.8(0.6)$ \\
\hline 16 & Fellowship & Head \& neck surgery & $6.1(1.7)$ & $8.7(0.3)$ \\
\hline 17 & $\mathrm{PhD}$ & Laboratory sciences & $6.4(1.1)$ & $8.6(0.6)$ \\
\hline 18 & Fellowship & Neuro-otology & $7.5(1.4)$ & $8.5(0.3)$ \\
\hline 19 & Short courses ${ }^{b}$ & $\begin{array}{l}\text { e.g. Philosophy of medicine, } \\
\text { Echocardiography, Exercise testing, } \\
\text { Endoscopy, Dialysis, Endosonography, Liver } \\
\text { transplantation }\end{array}$ & $7.8(1.0)$ & $8.4(0.6)$ \\
\hline 20 & $\mathrm{PhD}$ & Genetics & $8.2(1.7)$ & $8.4(1.4)$ \\
\hline 21 & $\mathrm{PhD}$ & Rehabilitation & $6.3(1.0)$ & $8.3(0.5)$ \\
\hline 22 & $\mathrm{PhD}$ & Medical ethics ${ }^{c}$ & $6.4(0.8)$ & $8.1(0.7)$ \\
\hline 23 & $\mathrm{PhD}$ & Stem cell research & $6.4(2.4)$ & $7.7(1.8)$ \\
\hline 24 & $\mathrm{PhD}$ & Health information management & $5.9(1.0)$ & $7.7(0.8)$ \\
\hline 25 & MD & Radiotherapy & $6.6(0.7)$ & $7.6(0.5)$ \\
\hline 26 & $\mathrm{PhD}$ & Neuroscience & $6.1(1.0)$ & $7.6(0.6)$ \\
\hline 27 & $\mathrm{PhD}$ & Health economics & $6.1(1.3)$ & $7.5(0.8)$ \\
\hline 28 & $\mathrm{PhD}$ & Health sciences & $7.3(1.0)$ & $7.5(0.2)$ \\
\hline 29 & $\mathrm{MSc}$ & Virology & $7.0(0.9)$ & $7.4(1.0)$ \\
\hline 30 & Specialty & Emergency medicine & $6.5(0.7)$ & 7.2 \\
\hline 31 & $\mathrm{MSc}$ & Neuroscience & $5.8(1.1)$ & $7.2(0.6)$ \\
\hline 32 & $\mathrm{PhD}$ & Biotechnology & $6.0(2.4)$ & $7.0(1.9)$ \\
\hline 33 & Fellowship & Paediatric uro-oncology & $6.4(1.9)$ & $7.0(1.4)$ \\
\hline 34 & MSc & Medical information science & $5.9(0.8)$ & $6.9(0.8)$ \\
\hline 35 & $\mathrm{PhD}$ & Drug development & $7.0(2.3)$ & $6.9(1.1)$ \\
\hline 36 & $\mathrm{PhD}$ & Nanotechnology in medicine & $6.0(1.0)$ & $6.9(0.9)$ \\
\hline 37 & Subspecialty & Heart rehabilitation & $5.3(1.0)$ & $6.7(0.5)$ \\
\hline 38 & MSc & Medical information technology & $6.0(0.9)$ & $6.7(0.6)$ \\
\hline 39 & MSc & Stem cell research & $5.2(1.5)$ & $6.4(0.9)$ \\
\hline 40 & Fellowship & Paediatric endourology & $5.3(0.9)$ & $6.3(0.7)$ \\
\hline 41 & Subspecialty & Dermatological immunology & $5.9(1.0)$ & $6.1(0.1)$ \\
\hline 42 & $\mathrm{PhD}$ & Virology & $5.1(2.1)$ & $6.0(1.4)$ \\
\hline
\end{tabular}




\begin{tabular}{|c|c|c|c|c|}
\hline \multirow[t]{2}{*}{ Rank } & \multirow[t]{2}{*}{ Degree } & \multirow[t]{2}{*}{ Subject } & \multirow{2}{*}{$\begin{array}{c}\text { Round } 2 \\
(n=102)\end{array}$} & \multirow{2}{*}{ 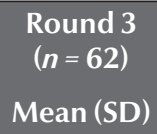 } \\
\hline & & & & \\
\hline 43 & $\mathrm{PhD}$ & Critical Management & $5.6(1.9)$ & $5.8(1.3)$ \\
\hline 44 & $\mathrm{PhD}$ & Medical Information Science & $5.1(1.1)$ & $5.7(1.0)$ \\
\hline 45 & $\mathrm{PhD}$ & Molecular Biotechnology & $5.2(1.3)$ & $5.5(1.1)$ \\
\hline 46 & MSc & Medical Physics & $5.1(1.0)$ & $5.2(0.9)$ \\
\hline 47 & $\mathrm{PhD}$ & Sports Medicine & $-(-)$ & $5.2(0.7)$ \\
\hline 48 & Subspecialty & Infant Liver Transplantation & $5.1(1.2)$ & $5.2(0.9)$ \\
\hline 49 & $\mathrm{PhD}$ & Geriatric Nursing & $5.2(1.9)$ & $5.2(1.0)$ \\
\hline 50 & $\mathrm{PhD}$ & Family Medicine & $5.1(0.6)$ & $5.1(0.6)$ \\
\hline
\end{tabular}

Means and standard deviation (SD) show participants' level of agreement on a 10-point scale ranging from completely disagree to completely agree. ${ }^{a}$ Post-residency training; ${ }^{b}$ Short complementary courses for specialists; ${ }^{c}$ Prerequisite $M D, D M D$ or PharmMD degree.

number of students should be increased or decreased. The greatest consensus among faculty members was to add several new masters programmes (Genetics; Rehabilitation; Health Information Management; Medical Education; and Drug Development), a BSc in Medical Information Technology and new $\mathrm{PhD}$ programmes in Oncology and in Midwifery and Fertility Health. There was a high level agreement in terms of omitting several associate degrees (Radiology; Public Health; and Laboratory of Sciences). Table 1 also shows that adding a new programme in Sports Medicine emerged in round 3.

High proportions of faculty members recommended increasing the number of students in the MSc in Hematology and in fellowship programmes in Ophthalmology, Infertility, Gastroenterology, Plastic Surgery, Nephrology, Cardiac Anaesthesia, Rheumatology and Cardiology (Table 3). Increasing students in a programme in Pediatric Cardiology emerged in round 3. Faculty members suggested decreasing the number of students in the MD in Medicine, the BSc Nursing and the specialties of General Surgery, Gynaecology and Obstetrics, and Psychiatry (Table 4).

\section{Teaching methods}

Table 5 shows Delphi participants' agreement about strategies for improving teaching methods. The strongest recommendations by faculty members were related to enhancing evidence-based and problem-based teaching methods, using more selfdirected learning methods, and establishing and expanding small-group, open-discussion and interactive teaching.

\section{Educational content}

Table 6 shows Delphi participants' agreement about strategies for improving the educational content of courses. The most important items suggested for educational content included utilizing more up-to-date scientific information, emphasizing research in course

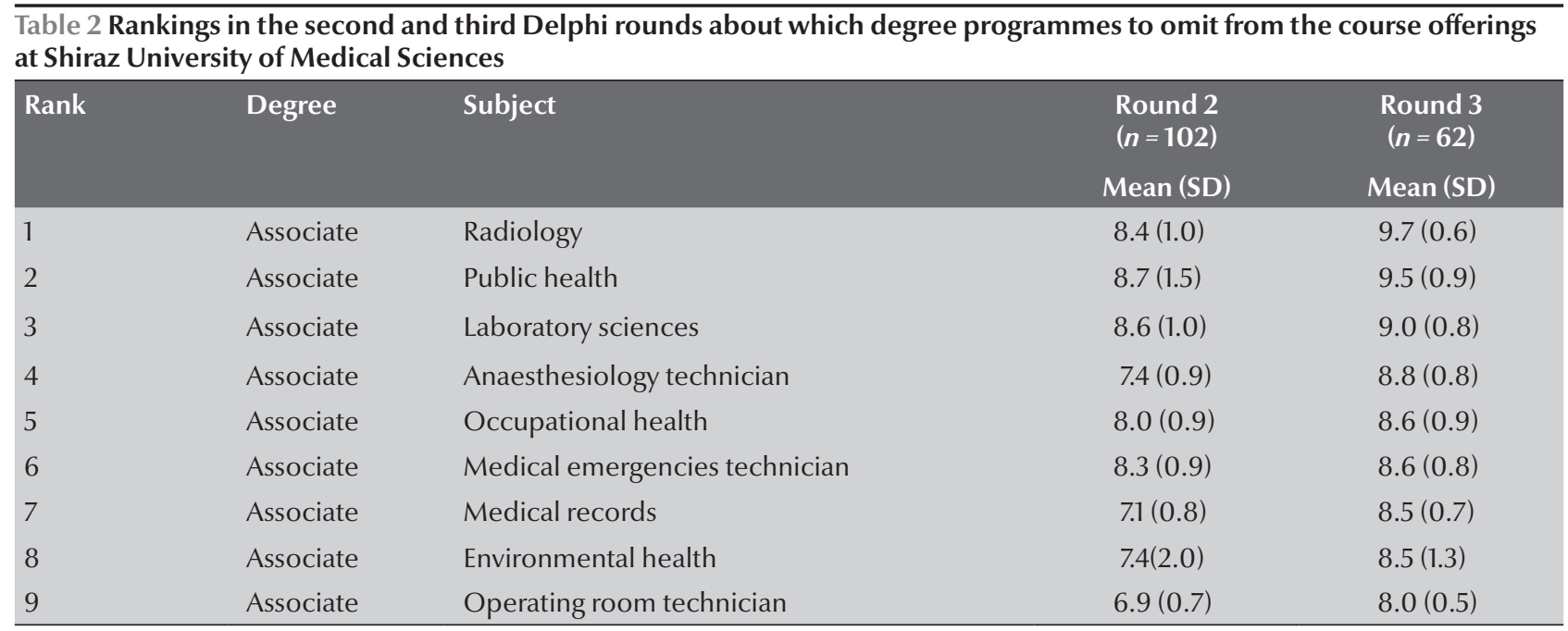

Means and standard deviation (SD) show participants' level of agreement on a 10-point scale ranging from completely disagree to completely agree. 


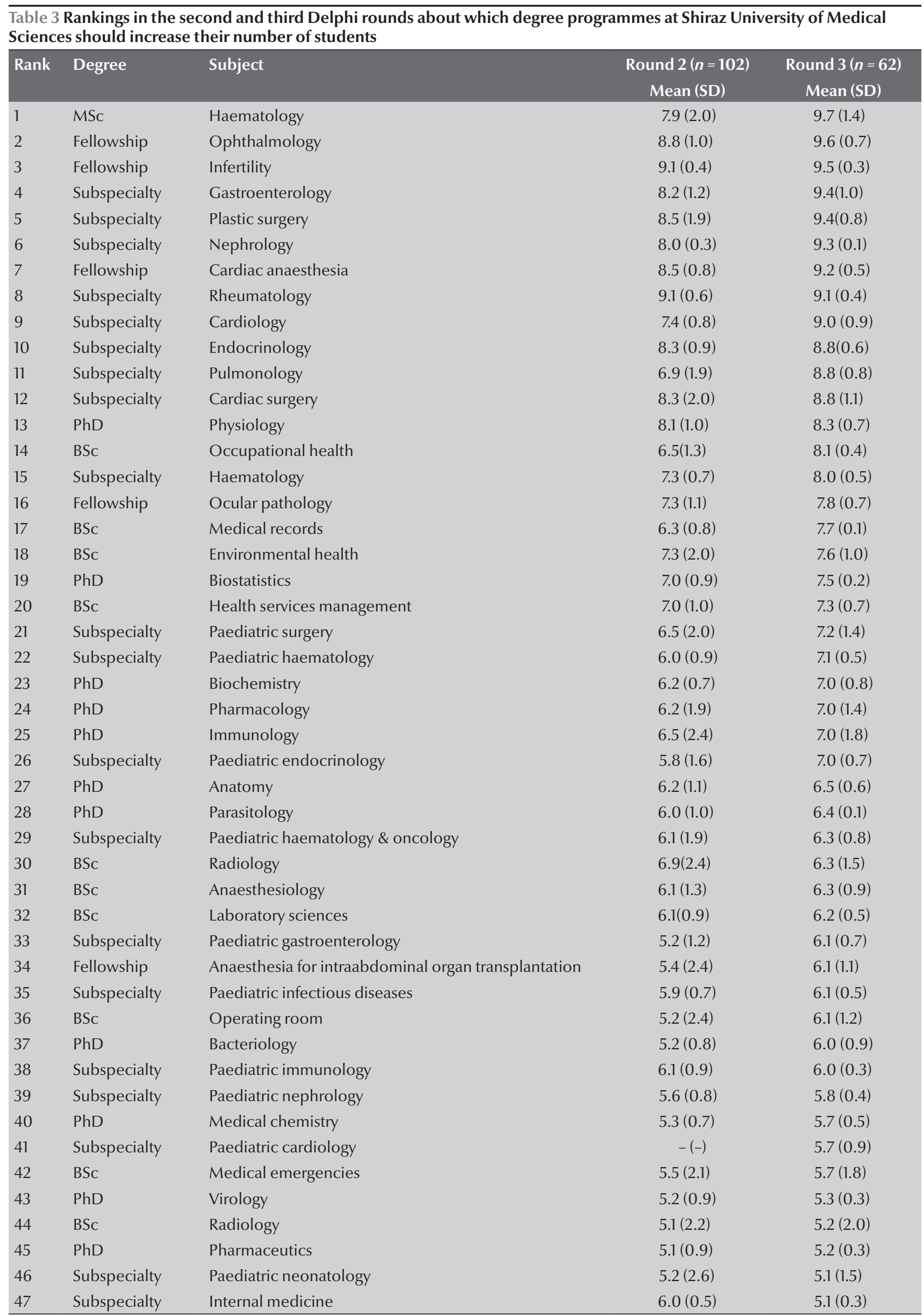

Means and standard deviation (SD) show participants' level of agreement on a 10-point scale ranging from completely disagree to completely agree. 


\begin{tabular}{|c|c|c|c|c|}
\hline \multirow[t]{2}{*}{ Rank } & \multirow[t]{2}{*}{ Degree } & \multirow[t]{2}{*}{ Subject } & \multirow{2}{*}{ 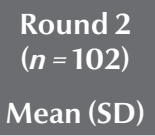 } & \multirow{2}{*}{$\begin{array}{c}\text { Round } 3 \\
(n=62) \\
\text { Mean (SD) }\end{array}$} \\
\hline & & & & \\
\hline 1 & MD & Medicine & $9.5(1.0)$ & $9.9(1.0)$ \\
\hline 2 & BSc & Nursing & $9.1(1.0)$ & $9.4(0.9)$ \\
\hline 3 & Specialty & General surgery & $8.5(0.7)$ & $9.3(0.6)$ \\
\hline 4 & Specialty & Gynaecology \& obstetrics & $8.7(0.9)$ & $9.1(0.9)$ \\
\hline 5 & Specialty & Psychiatry & $8.5(1.1)$ & $9.0(1.0)$ \\
\hline 7 & Specialty & Paediatrics & $7.7(0.5)$ & $8.7(0.4)$ \\
\hline 8 & Specialty & Oral \& maxillofacial surgery & $8.3(0.5)$ & $8.7(0.4)$ \\
\hline 9 & BSc & Midwifery & $8.4(1.9)$ & $8.6(1.3)$ \\
\hline
\end{tabular}

Means and standard deviation (SD) show participants' level of agreement on a 10-point scale ranging from completely disagree to completely agree.

contents, decreasing or eliminating basic and prerequisite courses which are not related to the aims of the degree programmes, and emphasizing practical courses in order to respond promptly to changes in students' and society's needs. Adding courses in sociology, art, logic and the philosophy of critical thought to academic courses emerged in the round 3 as a new item.

\section{Student evaluation techniques}

Table 7 shows Delphi participants' agreement about techniques for improving student evaluation. The most recommended items in this theme included using outcome-based evaluations, shifting from end-of-term to more continuous evaluation, allocating part of the evaluation towards a student research project, improving the quality of multiple-choice questions, and using more descriptive evaluations such as essays, reports and practical work.

\begin{tabular}{|c|c|c|c|}
\hline \multirow[t]{2}{*}{ Rank } & Teaching method & $\begin{array}{l}\text { Round } 2 \\
(n=102)\end{array}$ & $\begin{array}{l}\text { Round } 3 \\
(n=62)\end{array}$ \\
\hline & & Mean SD & Mean (SD) \\
\hline 1 & Enhance evidence-based learning programmes & $9.1(2.0)$ & $9.7(0.9)$ \\
\hline 2 & $\begin{array}{l}\text { Improve problem-based learning courses to encourage students to study } \\
\text { effectively }\end{array}$ & $8.7(1.4)$ & $9.4(0.7)$ \\
\hline 3 & Use more self-directed learning methods & $8.5(1.0)$ & $9.2(0.8)$ \\
\hline 4 & Establish and expand small-group, open-discussion and interactive teaching & $8.8(0.9)$ & $9.1(1.0)$ \\
\hline 5 & Use methods which are more practical and interesting for students & $8.4(0.9)$ & $8.9(0.4)$ \\
\hline 6 & Use new technologies and facilities & $8.3(1.0)$ & $8.6(0.8)$ \\
\hline 7 & Encourage students to use self-study and group study & $7.5(2.3)$ & $8.6(1.9)$ \\
\hline 8 & $\begin{array}{l}\text { Improving educational methods for e-testing, e-teaching, e-learning and } \\
\text { computer-assisted learning }\end{array}$ & $7.9(0.6)$ & $8.4(0.3)$ \\
\hline 9 & Increase student-centred teaching methods & $8.0(0.9)$ & $8.4(0.6)$ \\
\hline 10 & Use methods which are objective and comprehensible & $8.0(0.9)$ & $8.4(0.8)$ \\
\hline 11 & $\begin{array}{l}\text { Encourage students to read a variety of evidence related to the current } \\
\text { course to increase their access to information and creativity }\end{array}$ & $7.6(2.8)$ & $8.3(2.0)$ \\
\hline 12 & Use English as an international language in educational courses & $6.5(2.5)$ & $7.7(1.7)$ \\
\hline 13 & Add specific software tools to educational courses & $6.4(1.3)$ & $7.7(0.7)$ \\
\hline 14 & $\begin{array}{l}\text { Teach ambulatory care in clinical settings under faculty supervision with } \\
\text { workshop methods }\end{array}$ & $6.6(0.9)$ & $7.3(0.3)$ \\
\hline 15 & Use "Focal Points" as a method in practical teaching or training & $5.4(0.9)$ & $5.8(0.5)$ \\
\hline
\end{tabular}

Means and standard deviation (SD) show participants' level of agreement on a 10-point scale ranging from completely disagree to completely agree. 


\begin{tabular}{|c|c|c|c|}
\hline \multirow[t]{2}{*}{ Rank } & Educational content & $\begin{array}{l}\text { Round } 2 \\
(n=102)\end{array}$ & $\begin{array}{l}\text { Round } 3 \\
(n=62)\end{array}$ \\
\hline & & Mean (SD) & Mean (SD) \\
\hline 1 & Utilize up-to-date scientific information & $9.3(1.9)$ & $9.8(1.5)$ \\
\hline 2 & Emphasize research when determining course content & $9.3(0.5)$ & $9.7(0.5)$ \\
\hline 3 & $\begin{array}{l}\text { Decrease or eliminate basic and prerequisite courses which are } \\
\text { not related to the aims of the degree programme, and improve } \\
\text { their contents by emphasizing practical courses }\end{array}$ & $8.8(1.1)$ & $9.6(0.8)$ \\
\hline 4 & Choose educational content according to society's needs & $8.9(1.4)$ & $9.5(1.0)$ \\
\hline 5 & $\begin{array}{l}\text { Create variety in educational resources according to the latest } \\
\text { scientific developments in the world, as directed through } \\
\text { developed countries }\end{array}$ & $8.4(2.0)$ & $9.2(1.3)$ \\
\hline 6 & $\begin{array}{l}\text { Emphasize job requirements/skills when determining course } \\
\text { content }\end{array}$ & $8.5(1.4)$ & $9.2(0.4)$ \\
\hline 7 & $\begin{array}{l}\text { Eliminate useless materials from educational content of all } \\
\text { programmes and make the syllabi more effective and specific }\end{array}$ & $8.5(0.9)$ & $9.1(0.3)$ \\
\hline 8 & $\begin{array}{l}\text { Make educational content more flexible in order to respond } \\
\text { promptly to changes in students' and society's needs }\end{array}$ & $8.5(2.4)$ & $9.1(1.3)$ \\
\hline 9 & Separate the core curricula from non-core curricula & $5.8(1.9)$ & $8.7(0.8)$ \\
\hline 10 & Provide accurate compilations of practical training content & $8.0(1.4)$ & $8.7(0.6)$ \\
\hline 11 & $\begin{array}{l}\text { Merge educational materials vertically and horizontally and } \\
\text { provide courses as holistic training packages }\end{array}$ & $8.1(0.7)$ & $8.6(0.8)$ \\
\hline 12 & Emphasize professional ethics & $7.4(0.8)$ & $8.5(0.5)$ \\
\hline 14 & $\begin{array}{l}\text { Consider moral and cultural problems of Iranian society in } \\
\text { educational contents }\end{array}$ & $7.1(1.9)$ & $7.6(1.3)$ \\
\hline 14 & $\begin{array}{l}\text { Add courses such as sociology, art, logic and the philosophy of } \\
\text { critical thought to academic courses }\end{array}$ & $-(-)$ & $6.0(0.7)$ \\
\hline
\end{tabular}

Means and standard deviation (SD) show participants' level of agreement on a 10-point scale ranging from completely disagree to completely agree.

\section{Discussion}

Medical and health sciences schools around the world are changing in different aspects that involve the design of new curricula, the development of new learning tools and methods of evaluation, and the introduction of different educational strategies. The aim of these new programmes is to foster creative, motivated, knowledgeable and accomplished students who are likely to achieve success as medical practitioners. This process can feed back into efforts to enhance the quality of medical and health sciences education, which in turn leads to improvements in the health-care system and, ultimately, in people's quality of life [12]. A number of similar themes emerged from this study for improving the medical and health educational system at SUMS.

\section{Educational programmes}

A clear recommendation that emerged from our survey was to replace many associate degree programmes with higher degrees. This may reflect a perception that graduates with associate degrees are not well-prepared to find work in the health-care system and that workplace managers prioritize applicants with a higher degree in the same field [6]. The Iranian Ministry of Health and Education has also emphasized the need to replace these programmes with higher degrees [6]. Studies in other countries have reported that employers believe that many new graduates they hire are not well-prepared for the workplace in terms of education $[13,14]$, and it has been suggested that there should be feedback from workplaces and organizations to colleges and universities about the suitability of new graduates [14]. As mirrored in a World Bank report of contemporary labour markets in the Middle East and North Africa, medical graduates need the knowledge, skills and attitudes for competent patient care, as well as the capability to adapt to change, generate new knowledge and critically reflect on and improve their practice [15].

Generally the consensus about increasing $\mathrm{PhD}$, specialist and subspecialty programmes in preference to other degrees reflects changing trends in the Iranian population's health, including the greater importance of chronic diseases rather than acute and infectious diseases and the increasing 


\begin{tabular}{|c|c|c|c|}
\hline \multirow[t]{2}{*}{ Rank } & \multirow[t]{2}{*}{ Evaluation technique } & $\begin{array}{l}\text { Round } 2 \\
(n=102)\end{array}$ & $\begin{array}{l}\text { Round } 3 \\
(n=62)\end{array}$ \\
\hline & & Mean (SD) & Mean (SD) \\
\hline 1 & $\begin{array}{l}\text { Favour content-based evaluation and reforming the education } \\
\text { process on the basis of results (outcome-based evaluation) }\end{array}$ & $9.3(1.0)$ & $9.6(0.6)$ \\
\hline 2 & $\begin{array}{l}\text { Change examination periods from the end of the semester to } \\
\text { continuous daily, weekly evaluation }\end{array}$ & $7.9(1.7)$ & $9.5(0.4)$ \\
\hline 3 & Allocate part of the evaluation towards a research project & $9.0(1.3)$ & $9.3(0.8)$ \\
\hline 4 & $\begin{array}{l}\text { Revise multiple-choice examinations continuously as one of the } \\
\text { evaluation methods in order to improve the quality of the questions }\end{array}$ & $8.4(1.0)$ & $9.1(0.5)$ \\
\hline 5 & $\begin{array}{l}\text { Change sectional, limited and item-based tests in favour of more } \\
\text { descriptive evaluations such as essays, reports and practical works }\end{array}$ & $6.9(3.0)$ & $9.0(1.9)$ \\
\hline 6 & $\begin{array}{l}\text { Provide summative evaluations for basic sciences, clinical and } \\
\text { specialty examinations }\end{array}$ & $8.4(2.0)$ & $8.8(1.3)$ \\
\hline 7 & Use portfolios and logbooks for evaluation & $6.3(0.4)$ & $7.7(0.3)$ \\
\hline 8 & Provide both formative and summative assessment simultaneously & $5.8(1.1)$ & $6.9(0.6)$ \\
\hline 9 & Use computer-based methods of evaluation & $5.1(2.1)$ & $6.5(1.9)$ \\
\hline
\end{tabular}

Means and standard deviation (SD) show participants' level of agreement on a 10-point scale ranging from completely disagree to completely agree.

life expectancy of the population [16]. There are also trends in health care and education in the Islamic Republic of Iran into more specialized fields and interdisciplinary fields, and a greater emphasis on research and scientific production [17]. Furthermore advances in diagnostic and therapeutic technologies and growth in information and communication technologies worldwide have led to changes in patients' expectations of health services for curing diseases in an accurate and specialized way [17].

Some of the panellists' suggestions to develop the medical and health education programmes into more specialized degrees may be a response to general trends in society. For example, the suggestion to offer a PhD in Traditional and Complementary Medicine could reflect the trend towards increased use of alternative and traditional medicine in Iranian society [17]. Other societal trends, such as the ageing of the Iranian population [17] and increased incidence of road traffic injuries [18], may have influenced participants' consensus about developing an MSc in Rehabilitation. Despite the consensus to decrease the number of specialists in Gynaecology and Obstetrics, participants agreed about adding a $\mathrm{PhD}$ in Midwifery and Fertility Health, and this may reflect the cultural importance of fertility among Iranian society and the public's expectation for specialized treatment from health care services [19].

Reducing so-called "brain-drain", the loss of educated graduates with higher degree educations to other countries [17], could be another reason for our panellists' perception of the need to increase the number of $\mathrm{PhD}$ students and specialist courses. Since the trends affecting health care and medical education in the Islamic Republic of Iran are similar to those in other countries (including more developed countries), Iranian policy-makers could adopt policies that have proven effective in other countries when planning medical education [17].

\section{Teaching methods}

The enhancements in teaching methods agreed by the majority of faculty members in our study included utilizing more interactive, practical and student-centred methods, such as evidence-based learning (EBL) and $\mathrm{PBL}$, along with incorporating modern technologies, such as e-learning. The Association for Medical Education in Europe also reported that there was a need for changes in teaching methods in medical education; these included changing the sequence of academic qualifications, greater use of event-based training, integration of new educational technologies, e-learning programmes and PBL [7], all of which are consistent with the priorities agreed by our participants. Similarly, the Association of American Medical Colleges expressed their concern that medical education programmes have not kept up to date [20]. In addition, the Association of Faculties of Medicine of Canada, in their report on the future of medical education in Canada identified strategies to improve medical education such as addressing the hidden curriculum, diversifying learning contexts and adopting a competency-based approach to learning [8].

According to other studies studentcentred techniques are useful in terms of improving flexible knowledge; developing effective problem-solving skills, 
self-directed learning and effective collaboration skills; increasing students' motivation to be more creative; and facilitating graduates' capability to function effectively in an ever-changing, complex clinical environment [21-25]. The goals and methodology of PBL and EBL are similar in being likely to transfer from theoretical frameworks into more practical outcomes [26], which subsequently increase the criticalthinking and problem-solving skills that are most needed in today's workplaces [14]. There is also growing evidence that students graduating from $\mathrm{PBL}$ programmes are more comfortable seeking and using information [27], and that students and faculty are highly satisfied with the methods [28]. Therefore it is essential for policy-makers to develop new, up-to-date teaching methods in order to enhance practicality in the education system [29].

The importance of technological and societal factors for shaping an effective medical and health sciences education was discussed by Benor in 2000 [21]. According to Montazer et al. and Carnaby there is a growing interest in the application of modern technologies such as e-learning to improve educational systems $[30,31]$. The findings of Koyani and Mathews about including educational interventions such as webbased tools into health and medical education were also consistent with our findings [32].

\section{Educational content}

In order to improve the educational content of courses our faculty members agreed on providing more up-to-date scientific courses, emphasizing research and practical courses; adapting educational contents to society's needs and health concerns; and greater flexibility of content to adapt to future health needs/ changes in society. One of the most important approaches to making the educational content more practical is through establishing a close relationship between the medical/health sciences education system and the health care service [15,33]. Although the Islamic Republic of Iran is a successful example of the unification of health services and medical education into one ministry, the Ministry of Health and Medical Education [4], in the view of our faculty members and other researchers there are still some challenges to increasing the quality of this relationship and increasing the cooperation between these two different areas [34]. Another example in this area is the reform of the Institute of Medicine in Chicago that was built on patient-based training and research, team supervision and inter-field education for improving patient-centred primary-care practice [35]. The Association of Faculties of Medicine of Canada has recommended improving MD education by addressing community needs and promoting prevention and public health [8]. According to Darley there is also a need to increase the national fund for medical and health sciences education to keep medical and health sciences schools at the forefront of education for health services [36]. However, according to Scriven, relationships between local education authorities and health promotion departments can be difficult and have tended to become more competitive. The paper concluded that alliances between health care systems and medical education had an uncertain future [37].

\section{Student evaluation}

In the area of student evaluation our faculty members agreed on the need to develop evaluation techniques into outcome-based evaluations which are daily/weekly; allocating part of the evaluation to research work; and revising these evaluation techniques continuously. Until now the predominant methods of student evaluation in the Iranian system have been examinations consisting of multiple-choice questions, but other educational systems are trying to use more innovative methods [4]. Although to date the majority of our courses evaluate process, it is learner or patient outcomes that are increasingly the focus of interest in course evaluation $[38,39]$. This agrees with the consensus of the current study about the importance of outcome evaluation. Evaluation techniques are one of the most problematic areas in health care education especially in developing countries [40], and therefore provision of a suitable framework for evaluation is crucial for providing feedback to course directors/organizers and improving the educational content and educational methods.

\section{Conclusions}

In view of the rise in the number of educational institutions, student admissions to medical and health sciences programmes and teaching staff in the Islamic Republic of Iran [41], it is necessary to focus on improvements in the quality of education. Approaches that may be effective towards this aim, according to our respondents, included adding and/ or increasing the numbers of higher degree programmes in preference to associate degrees; providing more interactive, student-centred teaching methods; improving the educational content with more practical and research-based courses tailored to society's needs; and an emphasis on outcome-based student evaluation techniques. These improvements are suggested in the hope that they will be useful in supporting efforts in Islamic Republic of Iran and elsewhere to optimize medical and health sciences education.

\section{Acknowledgements}

The authors are thankful to all faculty members of Shiraz University of Medical Sciences for their participation in this research. We also thank Ms K. Shashok (Author AID in the Eastern Mediterranean) for help with manuscript editing.

Competing interests: None declared. 


\section{References}

1. Cooke $\mathrm{M}$ et al. American medical education 100 years after the Flexner report. New England Journal of Medicine, 2006, 355:1339-1344.

2. Nandiwada DR, Dang-Vu C. Transdisciplinary health care education: training team players. Journal of Health Care for the Poor and Underserved, 2010, 21:26-34.

3. Godet M. Chapter 2. From determinism to determination, from forcasting to 'strategic prospective'. In: From anticipation to action: a handbook of strategic prospective. Paris, United Nations Educational, Scientific and Cultural Organization, 1993:29-53.

4. Azizi F. Medical education in the Islamic Republic of Iran: three decades of success. Iranian Journal of Public Health, 2009, 38:19-26.

5. Marandi A. The integration of medical education and health care system in the Islamic Republic of Iran: a historical overview. Indian Journal of Medical Education, 2001, 1:8-11.

6. National 20-year horizon plan. Tehran, Ministry of Health and Education, Islamic Republic of Iran, 2009 [in Farsi].

7. Genn JM. AMEE medical education guide no. 23 (part 1): curriculum, environment, climate, quality and change in medical education-a unifying perspective. Medical Teacher, 2001, 23:337-344.

8. The future of medical education in Canada (FMEC): a collective vision for MD education. Ottawa, Association of Faculties of Medicine of Canada, 2010.

9. United Arab Emirates Vision 2021. United in ambition and determination. Abu Dhabi, United Arab Emirates, 2010 (http:// www.vision2021.ae/downloads/UAE-Vision2021-BrochureEnglish.pdf, accessed 8 December 2013).

10. Hsu CC, Sandford BA. The Delphi technique: making sense of consensus. Practical Assessment, Research and Evaluation, 2007, 12(10).

11. Powell C. The Delphi technique: myths and realities. Journal of Advanced Nursing, 2003, 41:376-382.

12. Dent JA, Harden RM. A practical guide for medical teachers, 2nd ed. Edinburgh, Churchill Livingstone, 2005.

13. Sufyan A. The school-to-work transition of young people in Syria. New York, International Labour Organization, 2006 (Employment Policy Paper 2007/3).
14. 14. Mellander GA. Changing higher education. Hispanic Outlook in Higher Education, 2007, 18:10-11.

15. 15. Unlocking the employment potential in the Middle East and North Africa: toward a new social contract. Washington DC, World Bank, 2004:196-200.

16. 16. Malekzadeh R. Mokri A, Azarmina P. Medical science and research in Iran. Archives of Iranian Medicine, 2001, 4:27-39.

17. 17. Rajabi F, Majdzadeh R, Mohsen Ziaee SA. Trends in medical education, an example from a developing country. Archives of Iranian Medicine, 2011, 14.

18. 18. Ardalan A et al. Road traffic injuries: a challenge for Iran's health system. Iranian Journal of Public Health, 2009, 38:98101.

19. 19. Aflatoonian A. Seyedhassani SM. Tabibnejad N. The epidemiological and etiological aspects of infertility in Yazd province of Iran. Iranian Journal of Reproductive Medicine, 2009, 7:117-122.

20. 20. Educating doctors to provide high-quality medical care: a vision for medical education in the United States. Washington DC, Association of American Medical Colleges, Group on Educational Affairs, 2004.

21. 21. Benor DE. Faculty development, teacher training and teacher accreditation in medical education: twenty years from now. Medical Teacher, 2000, 22:503-512.

22. 22. Hmelo-Silver CE. Problem-based learning: what and how do students learn? Educational Psychology Review, 2004, 16:235-266.

23. 23. Plsek PE, Greenhalgh T. Complexity science: the challenge of complexity in health care. British Medical Journal, 2001, 323:625-628.

24. 24. Schmidt HG, Rotgans JI, Yew EH. The process of problembased learning: what works and why. Medical Education, 2011, 45:792-806.

25. 25. Barrett T. The problem-based learning process as finding and being in flow. Innovations in Education and Teaching International, 2010, 47:165-174. 